\title{
Geochemistry of metamorphic-hosted iron ore deposit and associated silica caps in Mt. Arı, Bitlis, Eastern Anatolia: preliminary records and pathfinder elements for hydrothermal origin
}

\author{
Hakan Çoban a,*, \\ a Bitlis Eren University, Science and Architecture Faculty, TR-13000, Bitlis Turkey
}

\author{
ART I C LE INFO \\ Article history: \\ Received 23 August 2019 \\ Accepted 09 Sep. 2019 \\ Keywords: \\ Iron ore \\ Au-bearing silica caps \\ Hydrothermal origin \\ Mt. Arı \\ Bitlis \\ Eastern Anatolia
}

Received in revised form 05 Sep. 2019

\begin{abstract}
A B S T RAC T
Iron ore (magnetite-hematite) is one of the common ore deposits occurred in Bitlis and surrounding areas from Eastern Anatolia. A new Fe occurrence have recently been discovered in Mt. Arı (locally called as Gultik Mountain) at SE of Bitlis city. Fe ore presents in metamorphic basement rocks as predominantly disseminated-type and to lesser amount massive ore. The area also hosts silica-rich alteration zones. Here, the bulk samples from both disseminated Fe-ore and siliceous alteration zones have been geochemically analysed by XRF method. Obtained results show that the grade of Fe-ore as total $\mathrm{Fe}_{2} \mathrm{O}_{3}$ (wt.\%) increase from 2 wt.\% to 42 wt.\%, together with $\mathrm{MgO}$ (from 0.01 to 5.3 wt.\%,), $\mathrm{CaO}$ (from 0.13 to 1.90 wt. \%) and $\mathrm{Na}_{2} \mathrm{O}$ (from 0.42 to $4.93 \mathrm{wt} \%$ ), as a function of decreasing $\mathrm{SiO}_{2}$ (from 68 to 39 wt.\%) and $\mathrm{Al}_{2} \mathrm{O}_{3}$ (15 to 8 wt.\%). Significant amount of Co (36-160 ppm), Mo (4-13 ppm), As (0.5$3.7 \mathrm{ppm}), \mathrm{Hg}(2.3-4.0 \mathrm{ppm})$ and $\mathrm{Sb}(0.8-1.3 \mathrm{ppm})$ was determined in analyzed disseminated iron ore samples. Similarly, in the samples of silica caps, $\mathrm{SiO}_{2}$ range between 88 wt. $\%$ and 74 wt. $\%$, and decrease with increasing $\mathrm{Al}_{2} \mathrm{O}_{3}$ (from 0.01 to 20.85 wt.\%) and $\mathrm{TiO}_{2}$ (from 0.015 to 1.05 wt.\%). Other oxides do not show regular trends. Such siliceous zones also include remarkable amount of Au (from 7.8 $\mathbf{g r} / \mathbf{t}$ to $\mathbf{1 7 . 6} \mathrm{gr} / \mathrm{t}$ in some samples), Co (30-200 ppm), Mo (2-10 ppm), As (0.9-3.2 ppm), $\mathrm{Hg}$ (1.7-6.7 $\mathrm{ppm})$ and $\mathrm{Sb}(0.7-73 \mathrm{ppm})$ contents. LREE enrichment also exist in high-grade Fe-ore. Based on the first preliminary geochemical results, it is concluded that the metamorphic-hosted Fe ore and Au-bearing silica caps from Mt. Arı have most likely hydrothermal in origin, and leaching of silica and the removal of iron, formed the iron ore (hematite-magnetite) in the metamorphic basement rocks. As a new target area, the region has a powerful potential. The uplifting of the metamorphic massif and related postmetamorphic tectonics (possibly in Neo-tectonic period) gave way the prominent channels for emplacement of hydrothermal fluids in the area. Due to an episode of regional extensional tectonic, the Au-Co-As-Hg-Sb-Mo-bearing silica-rich hydrothermal fluids relocated into the metamorphic basement.
\end{abstract}

(C) 2019. Turkish Journal Park Academic. All rights reserved.

\section{Introduction}

In Eastern Anatolia, Bitlis and surrounding region host various types of economical ore deposits (as precious metals, e.g., Fe-Cu-Pb-Zn), industrial raw materials (e.g., barite, marble, phosphate) and construction materials (e.g., pumice, perlite, ignimbrite-Ahlat stone). Following to Oligo-Miocene
Arabian-Anatolian collision, regional uplifting and extensional tectonics released the most of the metamorphic- and ophiolite-related ores in the region (e.g. Helvacl, 1984; Çağatay, 1987; Hanilçi and Öztürk 2010; İmamoğlu et al., 2007; Çolakoğlu, 2005; Çolakoğlu et al., 2011; Yıldırım et al., 2016). These deposits are associated with metamorphic basement rocks (with barite), sedimentary rocks (with phosphates), Nemrut volcanism (with pyroclastics), and ophiolitic complex (with chromium, copper, iron).

\footnotetext{
* Corresponding author.

E-mail address: hcoban@beu.edu.tr
} 
Accordingly, it can be concluded that the Neo-tectonic period tectonism released the precious metal-bearing hydrothermal deposits to surface along with Bitlis-Zagros Suture Zone. In this regard, relative to $\mathrm{Fe}$ deposits related to ophiolites, occurrence of $\mathrm{Fe}$ ore and associated silica-rich alteration zones in metamorphic basement rocks at Mt. Arı (Bitlis) mountain leads to special interest. In this study, based on the first preliminary geochemical analyses on disseminated iron ore and associated silica-rich alteration zones at Mt. Arı from SE of Bitlis, the effects of hydrothermal fluids in their origin has been evaluated and discussed.

\section{Brief Geology}

Bitlis metamorphites and non-metamorphite cover rocks are known as 'Bitlis Metamorphite Belt' (Boray, 1975, 1976; Göncüoğlu and Turhan, 1984, 1985). This belt comprises Precambrian aged Hizan Group basement rocks (called as Lower Metamorphite Units), and overlying PaleozoicMesozoic aged Mutki Group basement rocks (called as Upper Metamorphite Units), Mesozoic aged Guleman ophiolite, Upper Cretaceous aged Kinzu Formation and Tertiary aged Kızılağaç Formation. Lower Metamorphite Units include amphibolite, paragneiss/flysch, eclogite and migmatites, which are intercut by metavolcanites and granitic intrusions, whereas Upper Units include metapelites and overlying metacarbonates (Şengün, 1993; Oyan and Tolluoğlu, 2006). The studied iron-ore deposit and silica caps occur in Mt. Arl, which is situated at SE of Bitlis, Eastern Anatolia (Fig. 1-2). Mt. Arl and surrounding areas represent by amphibolite, paragneiss/flsch, migmatite and granitoid rock groups of Lower Metamorphites. These units are called by Şengün (1993) as Yolcular metamorphites. Detailed mineralogical and petrographical properties of basement metamorphic rocks can be found in Oyan and Tolluoğlu (2006). The iron ore with magnetite-hematite in composition occurs strongly as disseminated-type, and lesser as massive-type in the area, and hosted by metamorphic basement rocks (lower metamorphite units of Bitlis massive) (Figs. 2-3). Disseminated-type iron can easily recognize by using magnet. Massive ore present as coarse blocks. Silica caps and siliceous alteration zones appear as yellowish colors in the area.

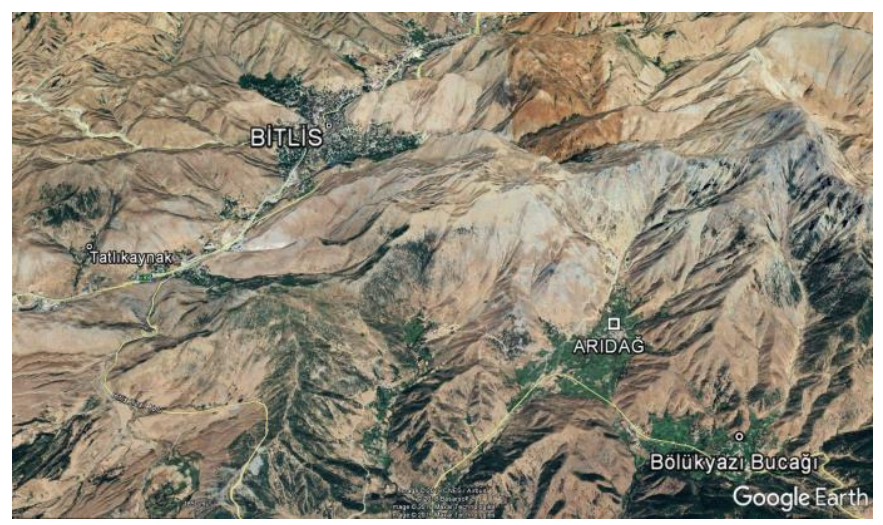

Figure 1. Location map of Mt. Arı (Bitlis) from Google Earth Image

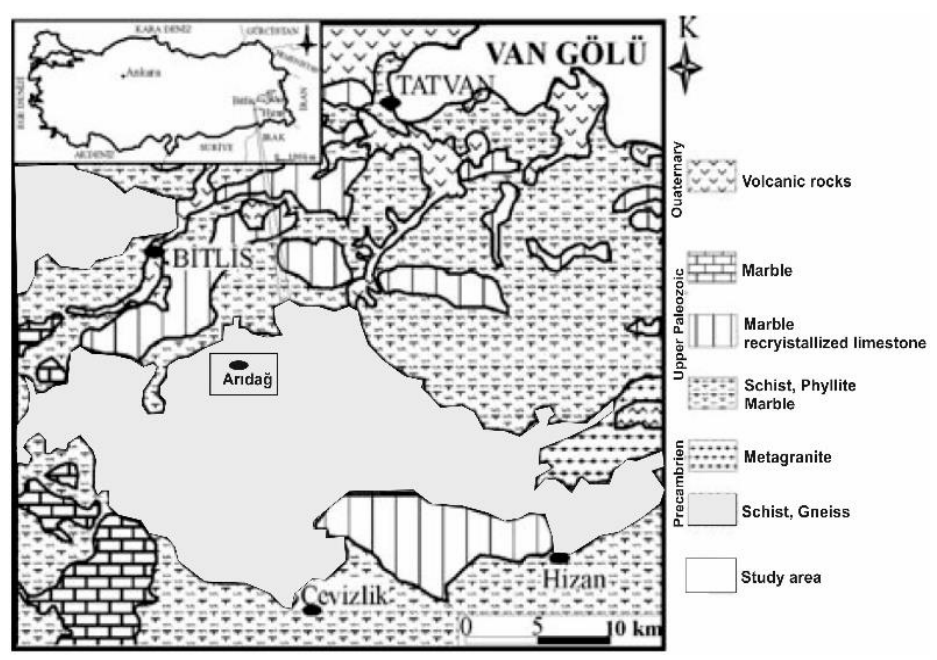

Figure 2. Geological map of the study area (modified from Oyan and Tolluoğlu, 2006)

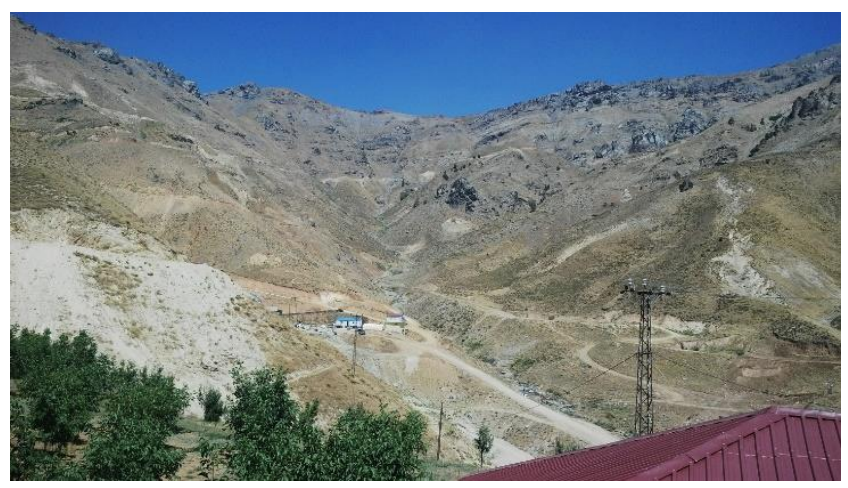

Figure-3. View of iron ore and silica-rich alteration zone hosted by metamorphic basement rocks from Mt. Arı.

\section{Materials and Method}

After crushing and grinding of the selected 15 handspecimens from iron-ore (5 samples) and siliceous alteration zones (10 samples) from the studied area, whole-rock and trace element analysis of powdered samples have been performed by XRF GEO-7220 method on Spectro X-LAB 2000 model PEDXRF device at Geosciences Application and Research Centre of Ankara University, Ankara, Turkey.

\section{Results and Discussion}

Major and trace element analyses of total 15 samples, from disseminated Fe ore (5 samples) and silica-rich alteration zones (10 samples) from Mt. Arı are given in Table- 1 . 
Table 1. Major (wt.\%) and trace element (ppm) analysis of silica caps and disseminated iron ore in Mt. Arı.

\begin{tabular}{|c|c|c|c|c|c|c|c|c|c|c|}
\hline & S1 & S2 & S3 & S4 & S5 & S6 & S7 & S8 & S9 & S10 \\
\hline Oxide & \multicolumn{10}{|c|}{ Silica-rich alteration zone } \\
\hline $\mathrm{SiO} 2$ & 88,3 & 85,2 & 81,2 & 80,8 & 79,3 & 77,8 & 76,9 & 75,6 & 74,2 & 73,8 \\
\hline $\mathrm{Fe} 2 \mathrm{O3}$ & 0,37 & 0,47 & 0,55 & 0,48 & 0,17 & 0,54 & 0,33 & 0,71 & 0,53 & 0,65 \\
\hline Al2O3 & 0,01 & 10,6 & 0,01 & 14,6 & 16,6 & 14,1 & 18 & 15,3 & 16,8 & 20,9 \\
\hline $\mathrm{MgO}$ & 0,45 & 0,16 & 0,37 & 0,16 & 0,02 & 0,13 & 0,01 & 0,08 & 0,07 & 0,04 \\
\hline $\mathrm{CaO}$ & 0,08 & 0,07 & 0,08 & 0,06 & 0,06 & 0,08 & 0,06 & 0,05 & 0,01 & 0,05 \\
\hline $\mathrm{Na} 2 \mathrm{O}$ & 0,1 & 0,25 & 0,06 & 0,34 & 0,24 & 0,04 & 0,04 & 0,21 & 0,16 & 0,04 \\
\hline $\mathrm{K} 20$ & 0,19 & 0,17 & 0,18 & 0,18 & 0,14 & 0,17 & 0,15 & 0,61 & 0,02 & 0,81 \\
\hline P205 & 0 & 0 & 0 & 0 & 0 & 0 & 0 & 0,02 & 0,01 & 0,01 \\
\hline TiO2 & 0,02 & 0,21 & 0,03 & 0,22 & 0,18 & 0,19 & 0,19 & 0,28 & 0,17 & 1,05 \\
\hline MnO & 0,01 & 0 & 0,01 & 0 & 0 & 0 & 0 & 0 & 0 & 0 \\
\hline $\mathrm{SO3}$ & 0,09 & 0,37 & 0,26 & 0,19 & 0,14 & 0,21 & 0,15 & 0,18 & 0,35 & 0,12 \\
\hline \multicolumn{11}{|l|}{ Trace } \\
\hline $\mathrm{Au}$ & $<0.1$ & 16,4 & $<0.1$ & 17,6 & 13,8 & $<0.1$ & $<0.1$ & $<0.1$ & $<0.1$ & 7,8 \\
\hline Y & 1,1 & 33,5 & 1,5 & 33 & 22 & 18,6 & 35 & 93,5 & 23 & 62,1 \\
\hline Mo & 2 & 9,5 & 2,3 & 3,9 & 6,3 & 4,4 & 3,4 & 7,6 & 3,5 & 3,6 \\
\hline Th & 0,4 & 0,6 & 0,4 & 0,5 & 0,4 & 0,4 & 0,6 & 2,5 & 0,9 & 1,1 \\
\hline $\mathrm{Zn}$ & 1,6 & 16,3 & 1,5 & 7 & 4,5 & 1,5 & 2,9 & 2,2 & 3,8 & 2,5 \\
\hline Co & 29,9 & 201 & 62,5 & 109 & 53 & 43,4 & 41 & 37,1 & 123 & 36,8 \\
\hline $\mathrm{Hg}$ & 2 & 6,7 & 1,9 & 4,6 & 3,1 & 2,3 & 2,3 & 1,9 & 1,7 & 2,4 \\
\hline As & 0,9 & 3,2 & 1 & 1,8 & 1,4 & 1 & 1,9 & 1,2 & 1,6 & 1,9 \\
\hline $\mathrm{Sb}$ & 0,8 & 1,4 & 0,7 & 2,5 & 1,4 & 1,7 & 2,4 & 15,5 & 1,2 & 73,4 \\
\hline Sn & 0,7 & 12,6 & 0,7 & 12,4 & 11,8 & 14,4 & 12,1 & 7,2 & 11,3 & 26,1 \\
\hline $\mathrm{U}$ & 5,7 & 6,3 & 5 & 5,3 & 5,9 & 6 & 8,6 & 6,8 & 4,9 & 6 \\
\hline La & 7,2 & 38,3 & 12,2 & 22,6 & 18,7 & 20,2 & 36,2 & 34,2 & 21,5 & 22,3 \\
\hline $\mathrm{Ce}$ & 9,9 & 38 & 9,8 & 41,7 & 27,4 & 24 & 50,1 & 71,3 & 32,8 & 62,4 \\
\hline
\end{tabular}

\begin{tabular}{|l|c|c|c|c|c|c|}
\hline & I1 & I2 & I3 & I4 & I5 \\
\hline Oxide & \multicolumn{5}{|c|}{ Disseminated iron ore } \\
\hline SiO2 & 68,3 & 67,9 & 60,3 & 50,1 & 39 \\
\hline Fe2O3 & $\mathbf{1 , 6 4}$ & $\mathbf{2 , 2 4}$ & $\mathbf{2 0 , 1}$ & $\mathbf{3 0}$ & $\mathbf{4 2 , 4}$ \\
\hline Al2O3 & $\mathbf{1 4 , 9}$ & $\mathbf{1 5 , 4}$ & 9,16 & 7,66 & 7,92 \\
MgO & 0,02 & 0,02 & $\mathbf{1 , 6 5}$ & $\mathbf{3 , 6 3}$ & $\mathbf{5 , 4}$ \\
\hline CaO & $\mathbf{0 , 1 3}$ & $\mathbf{0 , 1 2}$ & $\mathbf{0 , 5 5}$ & $\mathbf{1 , 1 4}$ & $\mathbf{1 , 9}$ \\
\hline Na2O & 0,42 & 0,43 & $\mathbf{4 , 9 3}$ & $\mathbf{3 , 3 5}$ & $\mathbf{2 , 1 2}$ \\
K2O & 12,6 & 12,5 & 0,14 & 0,21 & 0,22 \\
P2O5 & 0,13 & 0,12 & 0,03 & 0,04 & 0,02 \\
\hline TiO2 & 0,01 & 0,01 & 0,11 & $\mathbf{0 , 3 6}$ & $\mathbf{0 , 3 8}$ \\
MnO & $\mathbf{0 , 0 1}$ & $\mathbf{0 , 0 1}$ & $\mathbf{0 , 0 3}$ & $\mathbf{0 , 0 8}$ & $\mathbf{0 , 1 2}$ \\
SO3 & $\mathbf{0 , 2 3}$ & $\mathbf{0 , 2}$ & $\mathbf{0 , 1 2}$ & $\mathbf{0 , 3 1}$ & $\mathbf{0 , 1 9}$ \\
\hline Trace & & & & & \\
\hline Au & $<0.1$ & $<0.1$ & $<0.1$ & $<0.1$ & $<0.1$ \\
\hline Y & 53,8 & 30,1 & 44,2 & $\mathbf{1 0 5}$ & $\mathbf{1 4 2}$ \\
\hline Mo & 3,8 & 4,8 & $\mathbf{8 , 7}$ & $\mathbf{8 , 4}$ & $\mathbf{1 3 , 4}$ \\
Th & $\mathbf{7}$ & $\mathbf{1 0 , 7}$ & $\mathbf{1 9 , 4}$ & $\mathbf{2 2 , 1}$ & $\mathbf{5 8 , 6}$ \\
\hline Zn & 4,7 & 4 & $\mathbf{2 0 , 2}$ & $\mathbf{5 2 , 4}$ & $\mathbf{7 0 , 2}$ \\
Co & $\mathbf{1 2 9}$ & 36,2 & $\mathbf{1 2 4}$ & $\mathbf{1 6 1}$ & $\mathbf{1 1 4}$ \\
Hg & 3,3 & 2,3 & 2,6 & 3,3 & 4 \\
\hline As & $\mathbf{3 , 7}$ & $\mathbf{2 , 3}$ & 0,5 & 0,7 & 0,8 \\
\hline Sb & 1,3 & 0,9 & 0,8 & 1,1 & 1,1 \\
\hline Sn & 1,2 & 4,8 & 2,9 & 4,6 & $\mathbf{1 0 , 9}$ \\
U & $\mathbf{9 , 8}$ & $\mathbf{1 4}$ & $\mathbf{9 , 6}$ & $\mathbf{1 2}$ & $\mathbf{1 3}$ \\
\hline La & 8,3 & 8 & $\mathbf{2 5 , 6}$ & $\mathbf{3 5 , 4}$ & $\mathbf{4 5 , 2}$ \\
Ce & 11 & 11 & $\mathbf{2 7 , 3}$ & $\mathbf{4 3 , 5}$ & $\mathbf{8 8 , 6}$ \\
\hline
\end{tabular}

\subsection{Geochemistry of disseminated iron ore}

The major element diagram $\mathrm{Fe}_{2} \mathrm{O}_{3}$ versus $\mathrm{SiO}_{2}$ for disseminated iron ore samples exhibits a negative correlation characterized by the progressive increase in $\mathrm{Fe}_{2} \mathrm{O}_{3}$ as $\mathrm{SiO}_{2}$ decreases (Fig. 4, Table-1). The $\mathrm{Fe}_{2} \mathrm{O}_{3}$ (total) contents vary between 1.64 and 42.42 wt percent, and $\mathrm{SiO}_{2}$ contents between 39.04 and 68.30 wt percent. Three samples from iron ore samples exhibit elevated $\mathrm{Fe}_{2} \mathrm{O}_{3}$ content of $\sim 45 \mathrm{wt}$ percent. The ores with highest iron concentration have lowest $\mathrm{SiO}_{2}$ contents (Fig. 3). In contrast to the negative correlation of $\mathrm{CaO}, \mathrm{TiO}_{2}$ and $\mathrm{MgO}$, the $\mathrm{Al}_{2} \mathrm{O}_{3}$ contents decrease with decreasing $\mathrm{SiO}_{2}$ (Table-1). High $\mathrm{SO}_{3}$ (0.1-0.3 wt.\%) also observed in ore samples, respectively. Total La and Ce contents (range between 19-134 ppm), as Light Rare Earth Elements, show a positive correlation with $\mathrm{Fe}_{2} \mathrm{O}_{3}$, and increase with increasing Fe grade. The Fe ores display an enrichments of Y (up to $142 \mathrm{ppm}$ ), U (up to $14 \mathrm{ppm}$ ) and Th (up to $59 \mathrm{ppm}$ ) (Table-1). Remarkable amounts of Mo (up to $13.4 \mathrm{ppm}$ ), Zn (up to $70 \mathrm{ppm}$ ), Co (up to $161 \mathrm{ppm}$ ), $\mathrm{Hg}$ (up to 4 ppm), As (up to $3.7 \mathrm{ppm}$ ) and Sn (up to $10.9 \mathrm{ppm}$ ) also determined in iron ore. 


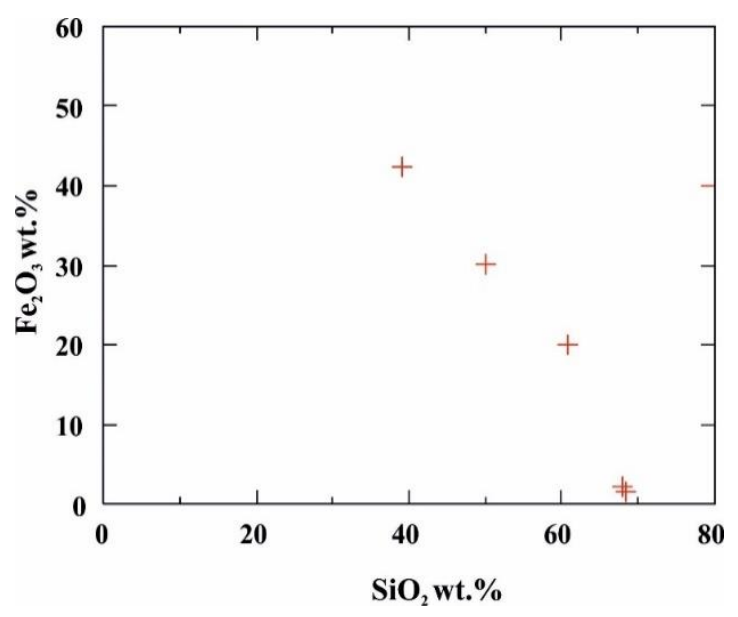

Figure 4. $\mathrm{SiO}_{2}$ (wt.\%) versus $\mathrm{Fe}_{2} \mathrm{O}_{3}$ (wt.\%) variation diagram for Mt. Arı disseminated iron ore samples.

\subsection{Geochemistry of silica-rich alteration zones}

In samples of silica caps in alteration zones, $\mathrm{SiO}_{2}$ range between $88 \mathrm{wt} . \%$ and $74 \mathrm{wt} . \%$, and decrease with increasing $\mathrm{Al}_{2} \mathrm{O}_{3}$ (from 0.01 to 20.85 wt.\%) and $\mathrm{TiO}_{2}$ (from 0.015 to 1.05 wt.\%) (Table-1). Other oxides do not show regular trends. High $\mathrm{SO}_{3}$ (up to 0.37 wt.\%) also observed in silica caps, respectively. Such siliceous zones also include remarkable amount of $\mathrm{Au}$ (from $\mathbf{7 . 8} \mathbf{~ g r} / \mathbf{t}$ to $\mathbf{1 7 . 6} \mathrm{gr} / \mathrm{t}$ in samples S2, S4, S5 and S10), Co (30-200 ppm), Mo (2-10 ppm), As (0.9-3.2 ppm), $\mathrm{Hg}$ (1.7-6.7 ppm), Y (up to $94 \mathrm{ppm}$ ), Sn (up to $26 \mathrm{ppm}$ ), U (up to $8.6 \mathrm{ppm}$ ) and $\mathrm{Sb}$ (up to $73 \mathrm{ppm}$ ).

\subsection{Pathfinder elements for hydrothermal fluids and formation of iron-ore}

At first sight, the appearance of Au-bearing silica-rich caps in alteration zones in the metamorphic basement rocks at Mt. Arı reflects a typical of gold-bearing iron-copper-gold deposits (e.g., Sillitoe, 2003). Coexisting of Fe ore and siliceous alteration zones also imply their formation by similar processes. As shown in Table-1, the chemical trends of major oxides observed in Fe-ore samples, such as decreasing $\mathrm{CaO}$, $\mathrm{TiO}_{2}, \mathrm{MgO}$ and $\mathrm{Fe}_{2} \mathrm{O}_{3}$ with increasing $\mathrm{SiO}_{2}$, also reflect typical of magmatic differentiation. Enrichment in La and Ce (as LREE) in Fe-rich ore, indicate the leaching of silica and removal of iron via hydrothermal fluids. This is similar to what occurs in Serra Norte (Brazil) iron ore deposits, where there is a genetic link between iron ore and magmatic hydrothermal fluids (Lobato et al., 2008; Figueiredo E Silva et al., 2008). In other word, remarkable enrichments in some trace elements e.g., Mo, Co, Y, U, Th, Hg, As, Sb and Sn, in both iron ore and silica caps in Mt. Arl also confirm that the magmatic hydrothermal fluids played a critical role in their genesis. In this regard, Nadoll et al., (2014) indicated that as main discriminator elements, $\mathrm{Mg}, \mathrm{Al}, \mathrm{Ti}, \mathrm{V}, \mathrm{Cr}, \mathrm{Mn}, \mathrm{Co}, \mathrm{Ni}, \mathrm{Zn}$ and $\mathrm{Ga}$ are commonly present at detectable levels and display systematic variations that can be used to fingerprint magnetite from different geological settings such as hydrothermal ore deposits. Similarly, Sn and Ga can also be used to distinguish the hydrothermal magnetite from igneous one (Kamvong et al., 2007). Pisiak et al., (2015) used to Sn versus $\mathrm{Ti}$ diagram for discrimination of hydrothermal magnetite (Fig. 5). As summary, pathfinder trace elements of Mt. Arı iron ore and silica-rich alteration zones are consistent with hydrothermal origin. It is proposed that these hydrothermal activities are associated with Neo-tectonic period magmatism. Following to regional uplifting of the metamorphic basements and associated extensional tectonic provided a prominent channels carrying the hydrothermal fluids to the area along with structural lineaments. Results also show that Mt. Arl, hosts not only for Fe-ore deposits but also economical important epithermal gold deposits.

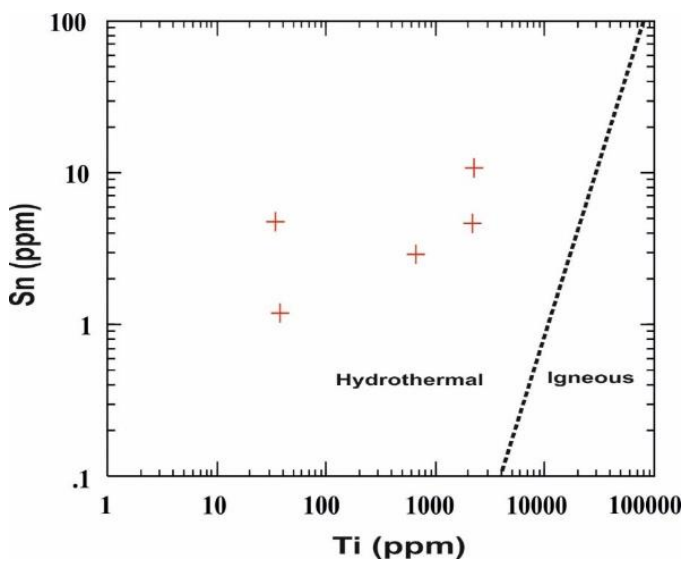

Figure 5. Sn (ppm) versus Ti (ppm) variation diagram (from Pisiak et al., 2014) for Mt. Arı disseminated iron ore samples.

\section{Concluding remarks}

The Mt. Arı iron ore deposit and associated gold-bearing silica caps are hosted by the lower metamorphite units of Bitlis Massif, Eastern Anatolia, Turkey. Their geochemical investigation revealed the followings:

1) High amount gold, ranging between $7.8-17.6 \mathrm{gr} / \mathrm{t}$, found in silica-rich alteration zones in Mt. Arı. This values imply that this region can be good target area for economically important gold-bearing silica-rich, possibly epithermal, deposits.

2) Coexisting of Fe-ore deposit with silicic alteration zones imply that there is a genetic linkage between them.

3) The presence of i) negative correlation between Fe and $\mathrm{Si}$, ii) enrichment of total La plus Ce with increasing $\mathrm{Fe}$ grade in iron ore, iii) enrichments of some pointer elements e.g., $\mathrm{Hg}$, As, Co, Mo, Y, Th, U and $\mathrm{Zn}$, not only in silica caps but also in Fe ore, reflect the strong affinity to hydrothermal fluids in their genesis.

4) It is proposed that the metamorphic-hosted Fe ore and Au-bearing silica caps from Mt. Arı have most likely hydrothermal (epithermal) in origin, and leaching of silica and the removal of iron, formed the iron ore (hematite-magnetite) in the metamorphic basement rocks. The uplifting of the metamorphic massive and related post-metamorphic tectonics in Neo-tectonic period possibly gave way the prominent channels for emplacement of 
hydrothermal fluids in the area. Extensional tectonic carried the Au-Co-As-Hg-Sb-Mo-Sn bearing silicarich hydrothermal fluids into the metamorphic basement.

5) To confirm the hydrothermal origin for Mt. Arl deposits, the area needs further detailed C-O-Sr-Nd isotopic, geochronological, mineral chemical and whole-rock chemical investigation.

\section{Acknowledgement}

I would like to thank to Mr. Kamuran Kanar from Kanar Mining Company (Bitlis), to his help during field work. I would also like to thank to Dr. Yusuf Kağan KADIOĞLU for conducting the geochemical analysis of samples at Geosciences Application and Research Centre of Ankara University, Ankara, Turkey.

\section{References}

Boray, A. 1975. Bitlis dolayının yapısı ve metamorfizması. Bulletin of Turkish Geological Association (T.J.K.), 18/1, 81-85.

Boray, A. 1976. Bitlis Metamorfitleri (Masifi) Üzerine. Yeryuvarı ve İnsan, 1, 74-76.

Çağatay, M.N., 1987. The Pancarlı nickel-copper sulfide mineralization, eastern Turkey. Mineralium Deposita. 22/3, 163-171.

Çolakoglu, A.R., 2005, Bitlis Masifi'inde (Hasbey-Van) gözlenen karbonat yankayaç $\mathrm{Pb}-\mathrm{Zn}$ cevherlesmesine yönelik ön bulgular: 58th Geological Congress of Turkey, 58, p. 78-81.

Çolakoğlu, A.R., Hanilçi, N., Günay, K. 2011. Cenozoic collisional tectonics and origin of $\mathrm{Pb}-\mathrm{Zn}-\mathrm{F}$ mineralization in the Bitlis Massif, SE Turkey. International Geology Review 53/14, 1593-1621.

Figueiredo e Silva, R. C., Lobato, L. M., Rosiere, C. A., 2008. A Hydrothermal Origin for the Jaspilite-Hosted, Giant Serra Norte Iron Ore Deposits in the Carajas Mineral Province, Para State, Brazil. in S Hagemann, C Rosiere, J Gutzmer \& N Beukes (eds), Banded Iron Formation-Related High-Grade Iron Ore. Society of Economic Geologists, Littleton, Colorado, USA, pp. 255-289

Göncüoglu, M.C., and Turhan, N., 1984, Geology of the Bitlis Metamorphic Belt, in Tekeli, O., and Göncüoglu, M.C. eds., International Symposium on Geology of the Taurus Belt Proceedings: Mineral Research and Exploration Institute of Turkey, p. 237-244.

Göncüoglu, M.C., and Turhan, N., 1985, Bitlis Metamorfik kuşağı orta bölümünün temel jeolojisi. Mineral Research and Exploration
Institute of Turkey (M.T.A), unpublished report, No: 7707, Ankara, $225 \mathrm{p}$.

Hanilçi, N., and Öztürk, H., 2010. Geochemical/isotopic evolution of $\mathrm{Pb}-\mathrm{Zn}$ deposits in the Central

and Eastern Taurides, Turkey: International Geology Review,DOI: 10.1080/00206811003680008.

Helvacı, C., 1984. Apatite-Rich Iron Deposits of the Avnik (Bingol) Region, Southeastern Turkey. Economic Geology, 79; 354-371.

İmamoglu, M. S., Nathan, Y., Coban, H., Soudry, D., Glenn, C. 2009. Geochemical, mineralogical and isotopic signatures of the Semikan, West Kasrik Turkish phosphorites from the Derik-Mazıdagl-Mardin area, SE Anatolia. International Journal Earth Science, 98, 1679-1690

Kamvong, T., Zaw, K., Siegele, R., 2007. PIXE/PIGE microanalysis of trace elements in hydrothermal magnetite and exploration significance: a pilot study. 15th Australian Conference on Nuclear and Complementary Techniques of Analysis and 9th Vacuum Society of Australia Congress. University of Melbourne, Melbourne, Australia.

Lobato, L.M., Figueiredo e Silva, R.C., Hagemann, S.G., Thorne,W.S., Zuchetti,M., 2008. Hypogene alteration associated with high-grade banded iron formation-related iron ore. In: Hagemann, S.G., Rosière, C.A., Gutzmer, J., Beukes, N.J. (Eds.), Banded Iron Formation-related High-grade Iron Ore. Reviews in Economic Geology, pp. 107-128.

Nadoll, P., Angerer, T., Mauk, J.L., French, D., Walshe, J. 2014. The chemistry of hydrothermal magnetite: A review. Ore Geology Reviews $61 ; 1-32$.

Oyan, V., Tolluoğlu, A.Ü., 2006. Bitlis Masifi'nde (Yolcular Metamorfiti) Na-Feldispat Bakımından Zengin Lökogranitik Kayaçlar: Na-Feldispat Kaynağı Olarak Bir Potansiyel. Yerbilimleri Dergisi. 3: 1-11.

Pisiak, L.K., Canil, D., Grondahl, C., Plouffe, A., Ferbey, T. Anderson, R.G. 2015. Magnetite as a porphyry copper indicator mineral in till: a test using the Mount Polley porphyry copper-gold deposit, south-central British Columbia (NTS 093A); in Geoscience BC Summary of Activities 2014, Geoscience BC, Report 2015-1, p. 141-150.

Sillitoe, R.H., 2003. Iron oxide-copper-gold deposits: Andean view. Mineral. Deposita 38, 787-812.

Şengün, M., 1993. Bitlis Masifi'nin metamorfizması ve örtü çekirdek ilişkisi. MTA dergisi. 115:1-13.

Yıldırım, N., Gören, B., Dönmez, C., Yıldırım, E., Akyıldız, M., Kalı, B., Tablacı, A., Günay, K., Eroğlu, M., 2016. Prekambriyen masifinde mağmatik Ni-sülfid cevherleșmesi: Doğu Türkiye (Bitlis-Pancarlı). 69. Türkiye Jeoloji Kurultayı, 334-337. 